\title{
Soil Classification and Fertility of the Peleforo Gon Coulibaly University's Agro-Pastoral Farm at Administrative Area of Korhogo (Northen Cote D'ivoire)
}

\author{
Loua Barthelemy Diomande ${ }^{1 *}$, Akotto Odi Faustin ${ }^{2}$, Alui Konan Alphonse ${ }^{3}$, Albert Yao-Kouame ${ }^{4}$ \\ ${ }^{1}$ Université Peleforo Gon Coulibaly de Korhogo, Institut de Gestion Agropastorale, Filière Economie et Gestion \\ Agropastorale, BP 1328 Korhogo, Côte d'Ivoire \\ ${ }^{3}$ Université Peleforo Gon Coulibaly de Korhogo, UFR Sciences Biologiques, Département Géosciences, BP 1328 \\ Korhogo, Côte d'Ivoire \\ ${ }^{2,3}$ Université Félix Houphouët-Boigny d'Abidjan, UFR des Sciences de la Terre et des Ressources Minières, \\ Département des Sciences du sol, 22 BP 582 Abidjan 22, Côte d'Ivoire
}

Received Date: November 17, 2020; Accepted Date: December 10, 2020; Published Date: January 15, 2021;

*Corresponding author: Loua Barthélémy DIOMANDE, Université Peleforo Gon Coulibaly de Korhogo, Institut de Gestion Agropastorale, Filière Economie et Gestion Agropastorale, BP 1328 Korhogo, Côte d'Ivoire;

Email: dibaloua@gmail.com

\section{Abstract}

To generate needed information for fertility of the University's agro-pastoral farm on a large scale, three representative soil profile pits (P1, P2 and P3) were carried out, and two fixed soil layers depths $(0-20,20-40 \mathrm{~cm})$ were taken (three replicates). 18 composite soil samples were airdried and passed through a 2-mm sieve prior laboratory analysis. Eutric Ferralsol-P1 (14.41 ha), Eutric Cambisol-P2 (6.53 ha) and Dystric Gleysol-P3 (8.82 ha) were found using CPCS and FAO's Guidelines for Soil. Soil reaction was strongly too slightly acid (5.0 to 6.5). Total nitrogen (TN), organic carbon (OC) and available phosphorus (Av. P) decreased with depth. OC, though being low (0.5 to $\left.1 \mathrm{~g} . \mathrm{kg}^{-1}\right)$,

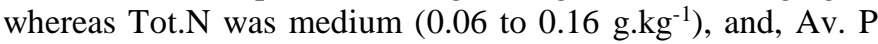
was rated as medium to high (21.0 to $\left.47.33 \mathrm{mg} \cdot \mathrm{kg}^{-1}\right)$. Cation exchange capacity ranged from medium $\left(5.12-6.68 \mathrm{cmol}^{\mathrm{kg}} \mathrm{kg}^{-}\right.$ $\left.{ }^{1}\right)$ to high $\left(15.1-18.2 \mathrm{cmol}_{\mathrm{kg}} \mathrm{kg}^{-1}\right.$. On the basis of silt/clay ratios, degree of weathering decreased from Dystric GleysolP3 > Eutric Ferralsol-P1 > Eutric Cambisol-P2. The soils were rated as having medium fertility and P3 was regarded as generally good agro-productive characteristics for savannah agriculture. Specific land management and cropping systems were recommended for sustainable utilization of soils.
Keywords: Cambisol; Ferralsol; Gleysol; Guidelines for Soil

\section{Introduction}

In a context of increasing degradation, parallel to the development of extensive and shifting slash-and-burn agriculture, there are many issues surrounding the soil. Considered as a non-renewable resource on a human scale, soil materials are at the heart of soil and ecological engineering questions in order to create more sustainable and resilient agricultural spaces [1]. From their extraction to their installation on an agricultural site, soil materials are subject to strong constraints: stripping, erosion, demographic pressure. The stripped or eroded layers most often correspond to the superficial horizons of agricultural land or to the first thirty centimeters stripped during the agrixoles $[\mathbf{2}, \mathbf{3}]$. The natural capacity of soils to support and supply nutrients for crop growth by optimizing their yields is the most important function that determines productivity in agriculture [4].

In order to assess the quality of our soil resources and their potential for producing food, fodder, fiber and fuel for present 
and future generations, detailed information on soil properties is needed. To this end, a good knowledge of the soil is essential for a good management of agricultural activities [5]. Information on the types and properties of soils is a powerful tool for decision-making in the development of agricultural land. The description of the soil allows a full understanding of its nature and properties. Thus, detailed knowledge of the soil assists in proper management of nutrient and moisture requirements to maximize crop production to the limits of allowable potential [6].

In recent decades, the problems of soil management and the improvement of their fertility have faced farmers in Africa south of the Sahara [7]. Most of the cultivable land in the northern part of Cote d'Ivoire has been used for cotton cultivation for more than half a century. The area of cultivable land has decreased considerably in the cotton basin and crop productivity has become low. The average cotton yield has remained below 1 ton per hectare in recent years [8]. Extensive monoculture cotton production increases the vulnerability of soils to erosion, degradation of their structure and loss of fertility [9]. A proper understanding of the soil properties, both physical and chemical, is necessary to optimize management processes [10]. In addition, the soil resource of the Cote d'Ivoire was studied at a scale of 1 : 2,000,000 [11].

These studies are of small scale and not comprehensive enough to draw sustainable development planning at basin level. Consequently, sustainable soil management practices that are based on the understanding of soil system are not available for most part of the country. Hence, a description of the soils is essential in any soil survey and in characterizing soil nutrients [12]. The soil profiles we see today are thus no longer the soils that were mapped before. In order to have useful soil database allowing proper decisions for assessing the potentials and constraints of the soils for different uses and land management options such as fertilizer application, improved tillage methods as well as crops management systems, pedagogical characterization of the study area has to be done. It is important to update data on soil characteristics on a large scale. The site of the farm, on which our study was carried out, has long been used for cotton cultivation. To this end, the sustainable management of the cropping systems that will be put in place requires recent and large-scale knowledge of the characteristics of the soils present on this site. The purpose of the work reported herein was to fill this observed gap. The main objective of the proposed study was to characterize the study area to generate needed information for fertility planning of the University's agro-pastoral farm on a large scale. Specifically, this study was curried out to examinee different agricultural contingencies that precipitate and sustain soil fertility decline in the savanna crop fields.

\section{Material and Methods}

\section{Pedological Survey}

The area is located in the northern part of Cote d'Ivoire, in the agro-pastoral experimental station in Peleforo Gbon Coulibaly University (PGCU), Korhogo, being bounded by the coordinates $9^{\circ} 03^{\prime} 45^{\prime \prime}$ to $9^{\circ} 00^{\prime} 30^{\prime \prime} \mathrm{N}$ and $5^{\circ} 30^{\prime} 10^{\prime \prime}$, $5^{\circ} 29^{\prime} 35^{\prime}$ 'W), having a total area about 30.0 ha. In order to obtain knowledge of the actual classes of soil, a pedological survey was carried out using a morphopedological study, based on the observation of open soil profile pits at September 2019. After separating the different soil contours, for their characterization profiles were taken, following the mapping rules for the 1:10,000 scale, along toposequences, themselves established after the opening of transects in given azimuthal directions.

The geographical genetic method was followed for the selection of points with augers and taking profiles, it is based on the variations of the soils according to their formation factors (relief, source material, climate, vegetation and time) and by the activity of man; which constitutes the basis of the classification of soils based on genetic principles. Spatial information about the distribution of soil profile pits was produced through data sets inventories, as reported by [13]. Three soil profile pits $(1.5 \mathrm{~m}$ long by $1.0 \mathrm{~m}$ wide and $2.0 \mathrm{~m}$ deep) were excavated at well-drained landscape, representing top (Profile 1), poorly drained representing slope (Profile 2) and depression, representing imperfectly drained (Profile 3). The boundaries of the representative soil profiles were photographed and described according to CPCS and FAO's" Guidelines for Soil Profile Description" [14, 15]. This evaluation being made according to criteria established [16].

Two fixed soil layers depths $(0-20,20-40 \mathrm{~cm})$ were taken randomly (three replicates) using a hand auger. Approximate 1 $\mathrm{kg}$ of 18 composite soil samples were air-dried and passed through a 2-mm sieve prior laboratory analysis. Soil particle sizes were determined by the Robinson pipette method [17] as well as organic-C, total-N, P-available (BrayI), and total-P. Soil $\mathrm{pH}$ was determined potentiometrically after equilibration with water in a 1: 2.5 soil/liquid ratio. Soil exchangeable $\mathrm{CEC}, \mathrm{K}, \mathrm{Ca}, \mathrm{Mg}$ and $\mathrm{Na}$ were also determined. Chemical analyses were performed as described [18]. In this study Soil reaction $(\mathrm{pH})$ was interpreted according to [19] and it can be very strongly and strongly acid $(4.5<\mathrm{pH}<5)$, moderately acid and slightly acid $(5<\mathrm{pH}<6.5)$, neutral $(6.5<\mathrm{pH}<7.5)$.

\section{Statistical Analysis}

Statistical treatments were emphasized using the dplyr (Wickham et al. [20]) and ggplot2 (Wickham [21]) packages for manipulating and plotting data. We studied relationships between $\mathrm{pH}$ and several soil nutrients by describing the quality of the different regression functions. Data set analysis were carried out in the $\mathrm{R}$ environment with the help of several packages [22] with used to create plots and analysis of variance $\mathrm{R}$ Core Team $[\mathbf{2 3}, \mathbf{2 4}]$. 


\section{Results}

\section{Physical Properties of the Soil Profile Horizons: Detailed Description}

Detailed profile descriptions and photographs of opened soil profiles for the soil positions: top, slope and depression soil series sampled elsewhere within the interior agro-pastoral of PGCU are shown in (Figures 1, 2 and 3), respectively. The soil was classed as having an orthic A and neocutanic B horizon. Although all of the soil types had a generic orthic A horizon, differences in diagnostic properties in the B resulted in differentiation at the soil form level. Smooth transitions between the A and B horizons confirm their youthfulness of structure. Horizon textural classes were generally fine sandy loam (depression), fine sandy clay loam (slope) and fine sand (top) in the A and B horizons. The lower horizons of the Dystric Gleysol also had yellow, grey and hydromorphic mottles present in the B horizon (Figure 3). Differences in soil physical properties of the soil profile horizons influenced the manner in which agro-pastoral soils drained.

\section{Site data of Profile P1: Well-drained Eutric Ferralsol}

Position: Top

Slope: $(0-0.2 \%)$

Eff. soil depth $>60(\mathrm{~cm})$

Parent material: schiste

Land use: extensive grazing

Vegetation: herbaceous

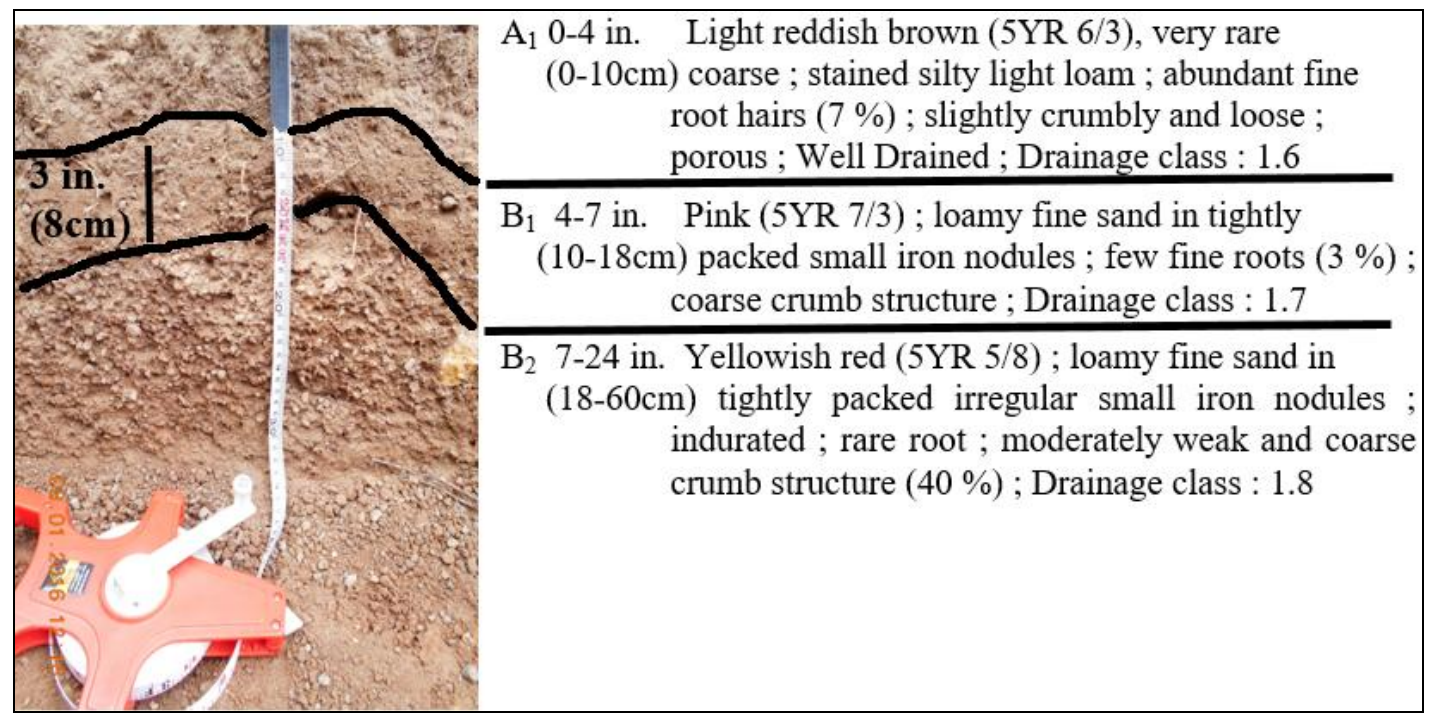

Figure 1: Representative of well-drained Eutric Ferralsol profile pits in top positions of a savannah agro-pastoral experimental station.

\section{Site data of Profile P2: poorly drained Eutric cambisol}

Position: Top

Slope: $(0-0.2 \%)$

Eff. soil depth $>80(\mathrm{~cm})$

Parent material: schiste

Land use: extensive grazing (HE)

Vegetation: savannah- regrowth 


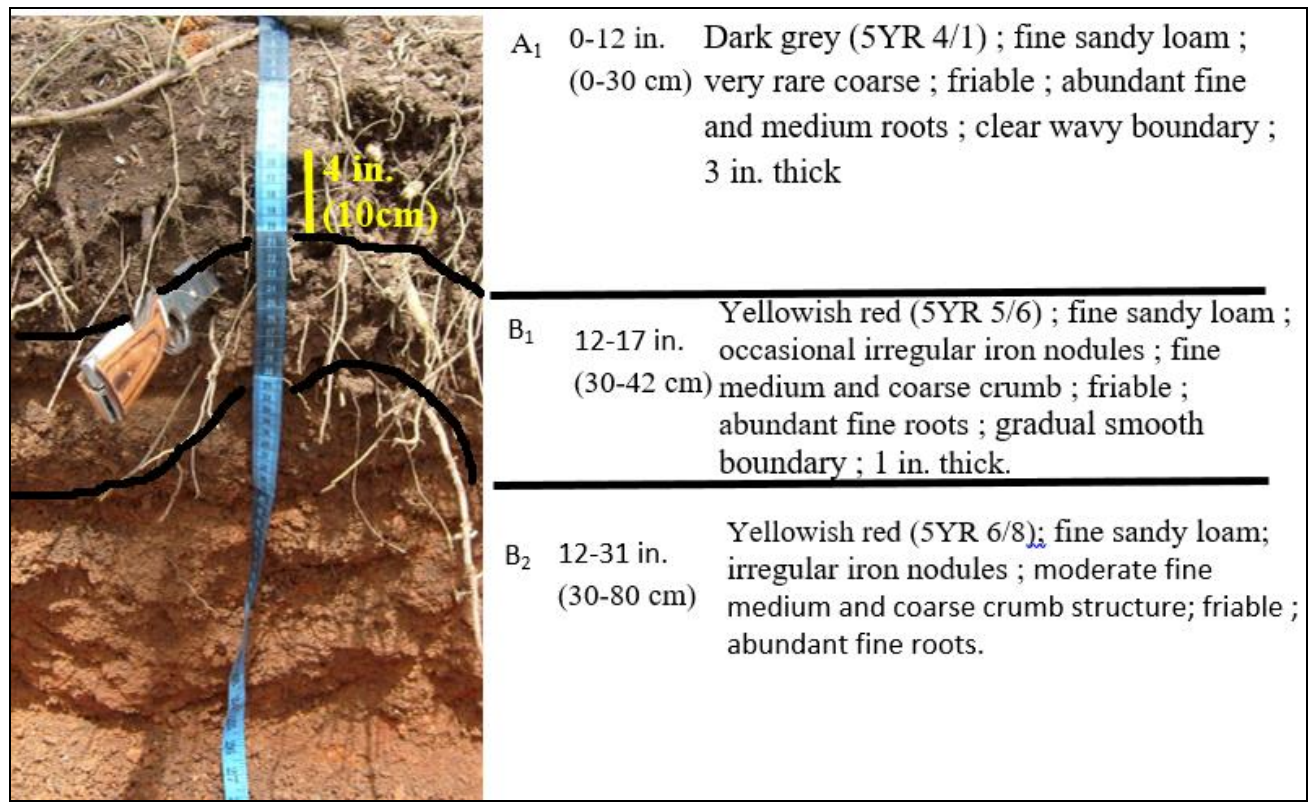

Figure 2: Representative of poorly drained Eutric Cambisol profile pits in slope positions of a savannah agro-pastoral experimental station.

\section{Site data of profile P3: imperfectly drained Dystric Gleysol}

Position: Depression

Slope: $(1.5-2.0 \%)$

Eff. soil depth $>200 \mathrm{~cm}$

Parent material: schiste

Land use: extensive grazing

Vegetation: herbaceous

\begin{tabular}{|c|c|c|c|}
\hline 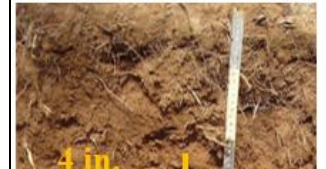 & $\mathrm{A}_{1}$ & $\begin{array}{l}0-17 \text { in. } \\
(0-43 \mathrm{~cm})\end{array}$ & $\begin{array}{l}\text { Yellowish brown }(10 \text { YR } 5 / 6) \text {; sandy clay } \\
\text { loam ; rare fine quartz gravel and rare } \\
\text { ironstone concretions ; plentiful fine and } \\
\text { medium roots }(10 \%) \text {; drainage class : } 1.9\end{array}$ \\
\hline & $B_{g}$ & $\begin{array}{l}\text { 17- } 66 \text { in. } \\
(43-167 \mathrm{~cm})\end{array}$ & $\begin{array}{l}\text { Yellow }(10 \mathrm{YR} 7 / 8) \text {; temporary periods of } \\
\text { inundation; very fine sandy clay loam with } \\
\text { common fine distinct mottles of yellow } \\
(10 \mathrm{YR} 8 / 6) \text { and weak red (10R4/8); } \\
\text { moderate fine and medium subangular } \\
\text { blocky structure; firm; few fine roots; } \\
\text { drainage class : } 2.0\end{array}$ \\
\hline & $\mathrm{B}_{\mathrm{G}}$ & $\begin{array}{l}66-79 \text { in. } \\
(167-200 \mathrm{~cm})\end{array}$ & $\begin{array}{l}\text { Yellow }(10 \mathrm{YR} 8 / 6) \text { with red }(2.5 \mathrm{YR} 4 / 6) \\
\text { mottles ; fine sandy clay ; strong gleying ; } \\
\text { rare roots; angular blocky structure; } \\
\text { slightly plastic; drainage class : } 2.5\end{array}$ \\
\hline
\end{tabular}

Figure 3: Representative of imperfectly drained Dystric Gleysol profile pits in depression positions of a savannah agro-pastoral experimental station.

\section{Physicochemical Characteristics of the Soils}

The physicochemical data set, fully described in this study were summarized in (table 1) where the soil fertility and physical property data averaged by slope position were presented. Organic carbon, though being generally low, was higher in Eutric cambisol (low Org.C range: 0.5 to $1 \mathrm{~g} . \mathrm{kg}^{-1}$ ), this means that the soil organic matter is generally low in the study area. 
However, on the topsoil, there is a good rate of mineralization of organic matter $(9 \leq \mathrm{C} / \mathrm{N} \geq 13)$, the content of which remains low. The CEC values were normal (normal range: 3.0 to 8.0 cmol. $\mathrm{kg}^{-1}$ ) in Eutric cambisol, high (high range: 8.0 to 15.0 cmol. $\mathrm{kg}^{-1}$ ) and very high (high range : >15.0 $\mathrm{cmol} . \mathrm{kg}^{-1}$ ) in Eutric Ferralsol and Dystric Gleysol, respectively.

\begin{tabular}{|c|c|c|c|c|c|c|c|c|c|c|c|c|}
\hline \multirow{2}{*}{$\begin{array}{l}\text { Horiz. } \\
\text { Design. }\end{array}$} & \multirow{2}{*}{$\begin{array}{c}\text { Depth } \\
\text { (cm) }\end{array}$} & \multirow{2}{*}{$\mathrm{pH}-\mathrm{H}_{2} \mathrm{O}$} & Org.C & Tot.N & $\mathbf{C} / \mathbf{N}$ & Tot.P & Av.P & CEC & $\mathrm{Ca}^{2+}$ & $\mathbf{M g}^{2+}$ & $\mathbf{K}^{+}$ & $\mathrm{Na}^{+}$ \\
\hline & & & \multicolumn{2}{|c|}{ g.kg-1 } & & \multicolumn{2}{|c|}{ mg.kg ${ }^{-1}$} & \multicolumn{5}{|c|}{$\left(\mathrm{cmol}^{2} \mathrm{~kg}^{-1}\right)$ Exch. Bases } \\
\hline & & & \multicolumn{10}{|c|}{ Eutric Ferralsol } \\
\hline $\mathrm{A}_{1}$ & $0-20$ & 6.2 & 1.06 & 0.1 & 10.3 & 312.33 & 47.33 & 7.43 & 1.72 & 0.88 & 0.11 & 0.0 \\
\hline \multirow[t]{2}{*}{$\mathrm{B}_{1}$} & $20-40$ & 5.4 & 0.47 & 0.06 & 15.7 & 337.33 & 31.33 & 9.68 & 0.98 & 0.78 & 0.10 & 0.0 \\
\hline & & & \multicolumn{10}{|c|}{$\begin{array}{l}\text { Eutric Cambisol } \\
\end{array}$} \\
\hline $\mathrm{A}_{1}$ & $0-20$ & 6.45 & 0.92 & 0.1 & 9.3 & 506.33 & 31.33 & 5.92 & 1.42 & 0.84 & 0.11 & 0.0 \\
\hline \multirow[t]{2}{*}{$\mathrm{B}_{1}$} & $20-40$ & 6.0 & 0.52 & 0.07 & 7.6 & 92.33 & 21.00 & 5.12 & 0.97 & 0.61 & 0.06 & 0.0 \\
\hline & & & \multicolumn{10}{|c|}{ Dystric Gleysol } \\
\hline $\mathrm{A}_{1}$ & $0-20$ & 5.25 & 1.72 & 0.16 & 13.2 & 131.33 & 31.33 & 18.20 & 0.70 & 0.68 & 0.06 & 0.0 \\
\hline $\mathrm{B}_{\mathrm{g}}$ & $20-40$ & 4.95 & 0.72 & 0.08 & 9.0 & 169.00 & 34.00 & 15.08 & 0.59 & 0.67 & 0.06 & 0.0 \\
\hline
\end{tabular}

Table 1 : Mean values of pH-H2O, Organic C, Total N, C/N, Total P, P2O5, CEC, basic cations of dominant soil types in the agropastoral experimental station of Peleforo Gbon Coulibaly University. Abbr.: Av. P as mg P2O5/kg soil.

The highest value of exchangeable $\mathrm{Ca}^{2+}$ was recorded at the location Eutric Ferralsol in surface $\mathrm{A}_{1}$ horizon $(1.72$ cmol. $\mathrm{kg}^{-1}$ ). At the locations of Eutric Ferralsol (B horizon), Eutric Cambisol (A horizon) and Dystric Gleysol (A horizon), higher values of exchangeable $\mathrm{Ca}^{2+}$ were recorded than in all other investigated locations, and values ranged from 0.70 cmol. $\mathrm{kg}^{-1}$ up to the above mentioned $1.72 \mathrm{cmol} . \mathrm{kg}^{-1}$ depending on the depth (horizon) (Table 1).

The highest value of exchangeable $\mathrm{Mg}^{2+}$ was recorded at the location Eutric Ferralsol in topsoil horizon $\left(0.88 \mathrm{cmol} . \mathrm{kg}^{-}\right.$ $\left.{ }^{1}\right)$. The recorded values of exchangeable $\mathrm{Mg}^{2+}$ were higher than in Eutric Cambisol and Dystric Gleysol locations, and values ranged from $0.61 \mathrm{cmol} . \mathrm{kg}^{-1}$ up to the above mentioned $0.88 \mathrm{cmol}^{\mathrm{kg}}{ }^{-1}$ depending on the depth (horizon) (Table 1).

The highest value of exchangeable $\mathrm{K}^{+}$was recorded at the locations of Eutric Ferralsol and Eutric Cambisol in upper horizon $\left(0.11 \mathrm{cmol} . \mathrm{kg}^{-1}\right)$, and the lowest value was recorded at the locations Eutric Cambisol and Dystric Gleysol in the deepest (B horizon) (Table 1).
The Av. P values were normal (normal range: 25.0 to 50.0 $\mathrm{mg} \cdot \mathrm{kg}^{-1}$ ) in A horizon $\mathrm{cm} \mathrm{depth,} \mathrm{and} \mathrm{the} \mathrm{lowest} \mathrm{value} \mathrm{(low}$ range: 15.0 to $25.0 \mathrm{mg} \cdot \mathrm{kg}^{-1}$ ) was recorded at the locations Eutric Cambisol and Dystric Gleysol in the deepest (B horizon) (Table 1). The phosphorus (Av. P) concentration of soil is generally a good, this means that in the area, it is encouraged to applying sligthy $\mathrm{P}$ fertilizers to take advantage of soil accumulated $\mathrm{P}$ and make Olsen-P content increase to a reasonable level (Table 1). The experiment was on a fertile, Eutric Ferralsol with potassium and phosphorus contents considered adequate for intensive grassland.

At the three dominant soil types observed, higher $\mathrm{pH}$ values were observed, ranging from 5.0 to 6.5. The soil $\mathrm{pH}$ in all the locations soils studied is generally higher (A horizon; $\mathrm{p}$ value $=0.013)$ and Dystric Gleysol appeared on average more acid than the others (Table 1, figure 4). The $\mathrm{pH}$ in study area soils had a significant positive relationship with $\mathrm{Ca}^{2+}, \mathrm{Mg}^{2+}$ and $\mathrm{K}^{+}$which means that the increasing soil $\mathrm{pH}$ improved $\mathrm{Ca}^{2+}$ content (Table 1, figure 5). 


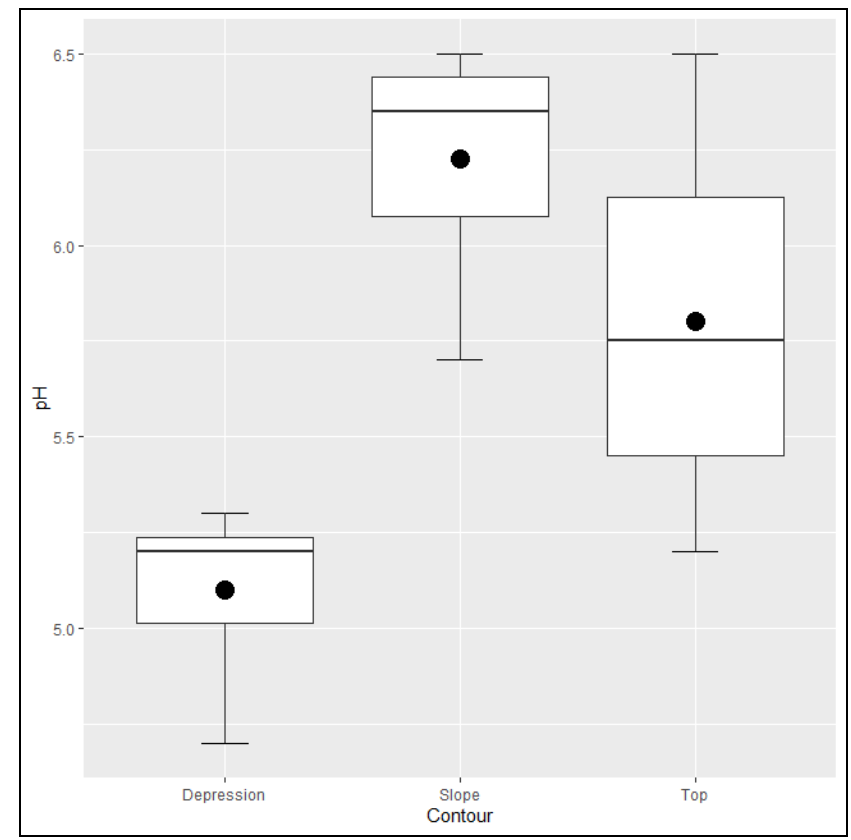

Figure 4: Box plot showing mean values of the soil $\mathrm{pH}$ by positions in many cases of a savannah agro-pastoral experimental station.

\section{The Mapping of Topsoil Properties}

In the chosen sector, the topographic survey is taken as the basis for making a detailed scale soil mapping (1:10, 000). The soils are classified and the agroproductive limiting factors are predetermined, and the characteristics of the relief and vegetation were recorded.
The results obtained to propose a cartography and classification of the soils of the agro-pastoral experimental station in PGCU was found that there are three dominant soil types (Eutric Ferralsol, Eutric cambisol and Dystric Gleysol). The most extensive soil was Eutric Ferralsol (14.41 ha), while Dystric Gleysol ( $8.82 \mathrm{ha}$ ) was the one with the best agroproductive characteristics than Eutric Ferralsol and Eutric cambisol (6.53 ha). (Figure 6).

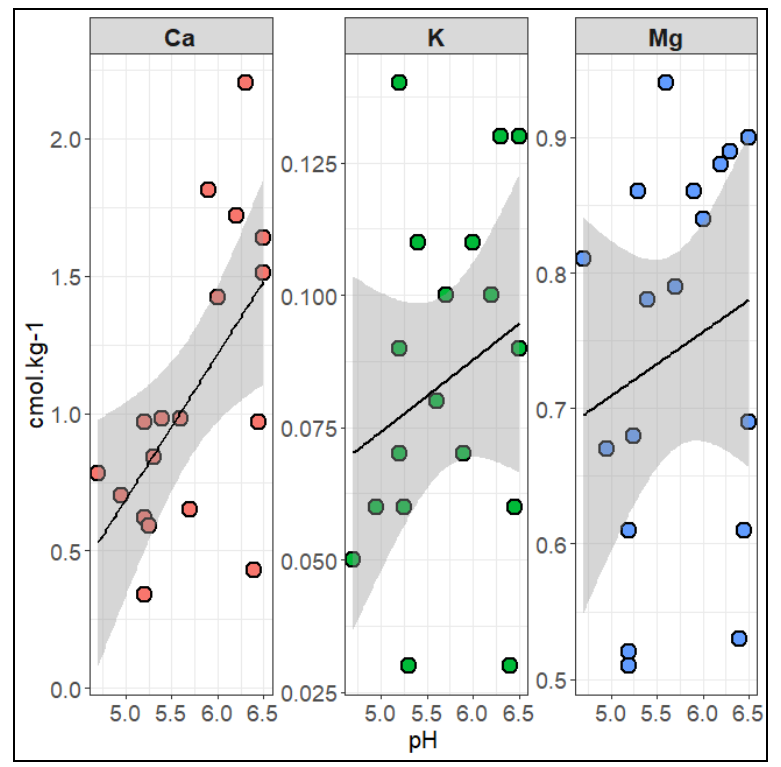

Figure 5: Model regression functions describing relationships between the more hydrogen ions held by the exchange complex of a savannah agro-pastoral experimental station. 


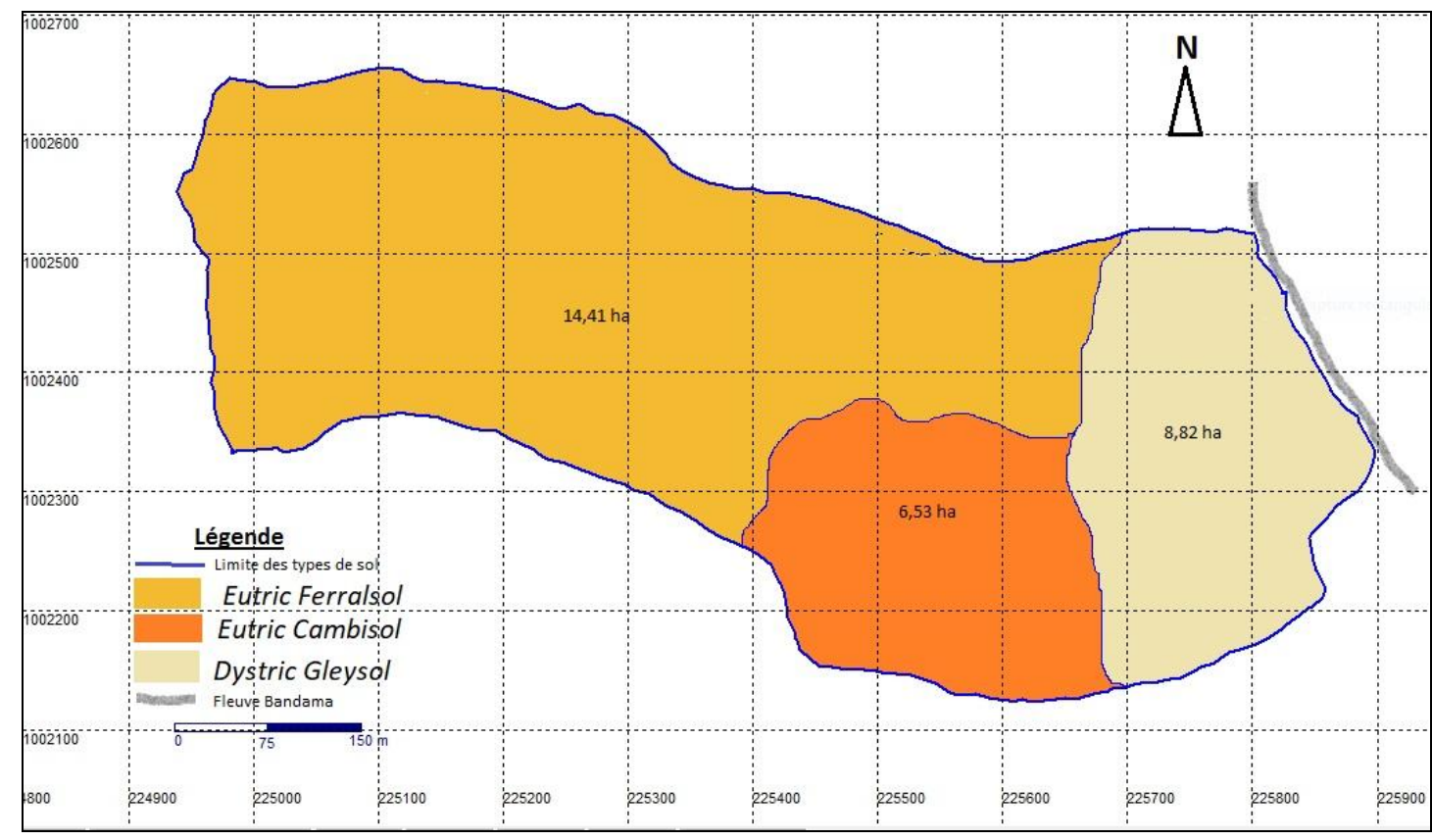

Figure 6: The initial polygon soil map at a scale of 1:10 000, savannah agro-pastoral experimental station of Peleforo Gbon Coulibaly University, Korhogo.

\section{Discussion}

A description of the soils is essential in any soil survey. This study describe the soil. It contains definitions for most soil properties and features and provides information for describing some soil properties change through time. Many properties was observed. This study reported the dominant soil types on that are most common in the northen part of Cote d'Ivoire Cambisols and Ferralsols and Gleysol on the parm. On the different lithotypes of the agro-pastoral experimental station of PGCU, soils with normal and high cationic exchange capacity, porousity, and sandy clay were developed, especially Cambisols and Ferralsols, whereas soils with very high cationic exchange capacity, low porousity and sandy clay were developed Gleysol. The soils are regarded as generally good for savannah agriculture. This is because of its deep depth and soil properties observed. The experiment was on a fertile, especially Eutric Ferralsol with potassium and phosphorus contents considered adequate for intensive grassland.

Organic carbon, though being generally low, was higher in Dystric Gleysol location, which may result from their higher clay content which stabilizes humus compounds and from smaller mineralization rate in waterlogged conditions, i.e. higher humus content at steady state. In Eutric Ferralsol and Eutric cambisol locations the diagnostic horizons of soil types showing the presence of well-transformed, dark-colored humified organic matter in the topsoil and the decline of organic matter content. The decline in organic matter content of many soils is becoming a major process of soil degradation, particularly in northern savannah Cote d'Ivoire [25]. The
Eutric Ferralsol and Eutric cambisol locations was considered as degraded soils and these soils are regarded as marginal for savannah-land agriculture. This is also because of their shallow depth (depth $<1 \mathrm{~m}$ ). According to Van-Camp et al. [26], degraded soils are not fertile and thus cannot maintain sustainable production.

The phosphorus (Av-P) concentration of soil is generally a good indicator for estimating the bioavailability of $\mathrm{P}$ and environmental risk in soils (Zhang et al. [27]). In the present study, the Av. P values in A horizon were regarded as best agro-productive, especially in the Eutric Ferralsol contours.

The soil reaction ranged from 5.0 to 6.5 units for all analyzed samples and Dystric Gleysol appeared on average more acid than the others. This acidity would generally be linked to the low cation content of the soil as reported [28]. They pointed out that in the north of the Cote d'Ivoire, this acidity is generally linked to the low levels of cation in the soil. Most plants thrive well in normal acidity of soils (pH 6.5 to 7.5). Thus, soils studied may present limitations to crop growth because of the low $\mathrm{pH}$ values of less than 5.5 which may limit availability of various plant nutrients such as phosphorus and bases [29]. According to Landon [30] phosphate ions combines with iron and aluminum to form compounds which are not readily available to plants in soils with $\mathrm{pH}$ of less than 5.5. Application of liming materials in Dystric Gleysol location may be considered necessary to raise the $\mathrm{pH}$ to favourable levels of around $\mathrm{pH} 6.5$ and 7.5. Alternatively, crops that tolerate to acidity are recommended for because plant species and varieties differ in the degree to which they tolerate $\mathrm{pH}$ values outside the range. 
The lowest value of exchangeable cations was recorded at the Dystric Gleysol location where soil $\mathrm{pH}$ was acid. Possible reasons for low values could be that the parent material on which soil has developed is poor in bases, linking in this [31]. According to Morales-Olmedo [32] most studies, consider a permanent flooding stress but in field conditions plants are often exposed to intermittent episodes of flooding and recovery. This transient waterlogging is very important because some specific damages, such as oxidative stress, may occur to a higher extent during re-aeration of tissues after a period of stress. The lowest value of exchangeable cations was recorded at the Dystric Gleysol can result, among other reasons, from oxidation reactions when waterlogged soils are re-aerated or dried after sampling [33]. The CEC values were normal (Eutric Ferralsol and Eutric Cambisol) to very high (Dystric Gleysol) [34]. It was because high clay and organic matter content in Dystric Gleysol $[\mathbf{3 5}, \mathbf{3 6}]$.

Inspection of the results shows that there was a close relationship between internal drainage hydraulic characteristics and pedological and physical properties of the dominant soil types. Variability in internal drainage showed greater consistency with the physical orientation and layering sequence of the profile horizons (Mavimbela and van Rendsburg [37]).

The results showed that without $\mathrm{P}$ fertilizers (NPK), the highest Av.P was in Eutric Ferralsol, the highest tot.N was in Dystric Gleysol, the highest CEC was in Dystric Gleysol, the highest Org.C was in Dystric Gleysol. From the above, The main soil types in the north were mainly Dystric Gleysol > Eutric Ferralsol > Eutric Cambisol. These soils usually have high productivity due to adequate moisture retention capacity and high organic matter. Except for the Cambisol, they were the most dominant types found in the northern savannah parts of the country. The most extensive soil was Eutric Ferralsol (14.41 ha), while Dystric Gleysol (8.82 ha) was the one with the best agro-productive characteristics than Eutric cambisol (6.53 ha). The Dystric Gleysols were regarded as the best agro-productive for savannah-land agriculture. This is because of its deep depth (depth $>2 \mathrm{~m}$ ).

According to the indications provided by the results of laboratory analysis and morphopedological data described above, we can say that the soils investigated, due to their good structure (lumpy), their permeability (predominantly sandy texture), their loose character, their depth, are capable of supporting different types of crops, whether they are perennial industrial crops of cotton, annual crops such as peanuts, soybeans, cowpeas, beans, corn, vegetable crops (chilli, peppers, eggplants) or market gardening crops (cucurbits, cucumber, watermelon, in the lowlands adjacent to watercourses).

\section{Conclusion}

This study was purposely conducted on 30 ha study area with different soil types that are extremely non-uniform both spatially and over the major indicators for soil characterization and evaluation of potential fertility of soils such as effective soil depth, organic carbon, cation exchange capacity, soil $\mathrm{pH}$, soil texture, and available phosphorus. Results reported that the soils of the agro-pastoral experimental station in PGCU, northen Cote d'Ivoire in large scale were Eutric Cambisols, Eutric Fluvisols and Dystric Gleysol as per FAO/UNESCO soil map of the world. These soil physical and chemical properties were influenced due to differences in land use systems. However, the morphological, physical, and chemical characteristic potentials of soils of PGCU in relation to soil fertility. Under these conditions the main soils that were formed were Cambisols, Fluvisols and in some lower parts, Gleysols can occur, although not very frequently. The Dystric Gleysols were regarded as the best agro-productive for savannah-land agriculture The results showed successful implementation of this proposed method, an extension of this study to different areas with different ranges of agricultural soil types are required to generalize the results presented.

\section{Acknowledgements}

We thank the anonymous reviewers who helped improve the early version of the manuscript.

\section{References}

1. FAO (2015) Soil is a non-renewable resource. Food and Agriculture Organization of the United Nations 2-3.

2. Cheverry C, Gascuel C (2009) Sous les pavés, la terre. Connaître et gérer les sols urbains. Omniscience, Montreuil, 485, COMBE.

3. Marié X, Rossignol J-P (1999) The "reconstituted anthropic soils" for landscaped areas. In Lemaitre, M., Lemattre P, \& Lemaire F (eds), International Symposium on Urban Tree Health. Paris, France. $\mathrm{N}^{\circ} 496: 361-367$.

4. Spiertz JHJ (2010) Nitrogen, sustainable agriculture and food security. A review. Agron. Sustain. Dev. 30:43-55.

5. Dijkerman JC (1969) Soil resources of sierra leone, West Africa. Afr. Soils 14:85-206.

6. Esayas A, Debele B (2006) Soil survey in Ethiopia: past, present and future. Addis Abeba, Ethiopia: Proceedings of the seventh conference of the Ethiopian Society of Soil Science on soils for sustainable development. 67-79.

7. Kanté S (2001) Gestion de la fertilité des sols par classe d'exploitation au Mali-Sud. Tropical Resources Management Papers, Wageningen University, No. 38.

8. Tuo L (2015) La baisse des rendements du coton inquiète en Côte d'Ivoire, Coton-Côte d'Ivoire, APA.

9. FAO 2015. Mesurer la durabilité des systèmes de culture du coton. Division de la production végétale et de la protection des plantes de la FAO, Comité consultatif International du cotonRome.

10. Zebire DA, Ayele T, Ayana M (2019) Characterizing soils and the enduring nature of land uses around the Lake Chamo Basin in South-West Ethiopia. J. Ecol. Environ 43:1-32.

11. Dabin B, Leneuf N, Riou G (1960) Carte pédologique de la Côte d'ivoire à $1 / 2000000$. Notice explicative. Publiée 
par le secrétariat d'état à l'agriculture, Direction des sols, Abidjan, Côte d'Ivoire 1-39.

12. Bobryk WC, Brenton $D$, Kitchen $R N$, Shanahan FJ, Sudduth AK (2016) Validating a digital soil map with corn yield data for precision agriculture decision support Agron. J 108-957.

13. Buell GR., Markewich HW, Kulisek R, Pollard S, TT Cook (2004) Site-specific soil-carbon (S3C) database for mineral soils of the Mississippi River basin, USA. USGS open-file report 2004-1227.

14. CPCS (1967) Classification des sols. Grignon, France, Ecole nationale supérieure agronomique 87.

15. FAO, ISRIC, AISS (1999) Base de référence mondiale pour les ressources en sol. Rapport sur les ressources en sols du monde 84:1-101.

16. Baize D, Jabiol B (2011) Guide pour la description des sols. Ouvrage-article, Edition Versailles [FRA] : Quae 428.

17. Gee GW, Bauder JW (1986) "Particle-size analysis," in Methods of Soil Analysis. Part 1. Physical and Mineralogical Methods, A. Klute, Ed., vol. 9 of Agronomy, Madison, Wis, USA, 2nd edition.

18. Page AL, Miller RH, Keeney DR (1996) Methods of Soil Analysis, Chemical and Microbiological Properties. Part 2, vol. 9 ofASA Monograph, American Society of Agronomy, Madison, Wis, USA, 2nd edition.

19. Arrouays D, Antoni V, Bardy M, Bispo A, Brossard M (2012) Fertilité des sols : conclusions du rapport sur l'état des sols de France, Innovations Agronomiques 21:1-11.

20. Wickham H (2016) rvest: Easily Harvest (Scrape) Web Pages. R package version 0.3.2.

21. Wickham H, Chang W, Henry L, Pedersen TL, Takahashi K, et al. (2018a) Ggplot2: Create Elegant Data Visualisations Using the Grammar of Graphics. R package version 3.1.0.

22. Wickham H, François R, Henry L, Müller K (2018b) dplyr: A Grammar of Data Manipulation. $\mathrm{R}$ package version 0.7.8.

23. R Core Team R (2019) A Language and Environment for Statistical Computing, $\mathrm{R}$ Foundation for Statistical Computing, Vienna, Austria, available at: http://www.Rproject.org.

24. R Studio Team, RStudio (2018) Integrated Development Environment for R, RStudio, Inc., Boston, MA.

25. Diomandé LB, Brahima K, Etienne VT, Tié BT, YaoKouamé A (2014) Occurrence and leave extractable essential oil of Lippia multiflora M. (Verbenaceae) as affected by soil acidity, carbon, nitrogen and phosphorus contents in north Côte d'Ivoire. Environment and Natural Resources Research 4:115-127.

26. Van-Camp L, Bujarrabal B, Gentile AR, Jones RJA, Montanarella L, et al. (2004) Reports of the Technical Working Groups Established under the Thematic Strategy for Soil Protection, EUR 21319 EN/3, 872, Office for Official Publications of the European Communities, Luxembourg.

27. Zhang W, Wang Q, Wu Q, Zhang S, Zhu P, et al. (2020) The response of soil Olsen-P to the $\mathrm{P}$ budgets of three typical cropland soil types under long-term fertilization. PLoS ONE, 15:1-17.

28. Diomandé LB, Yao-Kouamé A, Koné B, (2016) Types de sol et chémotypes d'huile essentielle de Lippia multiflora, Ebook, Editions Universitaires Européennes.

29. Marschner H (1995) Mineral nutrition of higher plants. 2nd edition. London, Academic Press 889.

30. Landon JR (1991) Booker Tropical Soil Manual, A handbook of soil Survey and Agricultural Land evaluation in the tropics and subtropics. Longman publication. London 500.

31. Moreira BG, Dos SJCB, Souza JVS, Almeida DE, Araújo FJC, et al. (2018) Association between parent materials and soil attributes along different geological environments in western pará, brazil. Acta Amazonica 48:261-270.

32. Morales-Olmedo M, Ortiz M, Sellés G (2015) Effects of transient soil waterlogging and its importance for rootstock selection. Chilean Journal of Agricultural Research 75:45-56.

33. Ferreyra R, Selles G, Pinto M, Morales M, Seguel O (2011) Effect of soil air capacity on water relations and vegetative growth of 'Thompson Seedless' grafted on different rootstocks. Preliminary results. Acta Horticulturae 889:145-150.

34. Assa A, (2005) Précis de pédologie à l'Usage des Etudiants du Second Cycle des Etudes Universitaires. Editions Universitaires : Côte d'Ivoire; 92.

35. Klamt E, Van Reeuwijk LP (2000) Evaluation of morphological, physical and chemical characteristics of Ferralsols and related soils. Rev. Bras. Cienc. Solo 24:573-587.

36. Tomašić M, Zgorelec Ț, Jurišić A, Kisić I (2013) Cation Exchange Capacity of Dominant Soil Types in the Republic of Croatia. Journal of Central European Agriculture 14:937-951.

37. Mavimbela SSW, Van Rensburg LD (2013) Estimating hydraulic conductivity of internal drainage for layered soils in situ. J. Hydrol. Earth Syst. Sci 17:4366-4366.

Citation: Diomande LB, Faustin AO, Alphonse AK, Yao-Kouame A (2021) Soil Classification And Fertility Of The Peleforo Gon Coulibaly University's Agro-Pastoral Farm At Administrative Area Of Korhogo (Northen Cote D'ivoire). Adv in Agri, Horti and Ento: AAHE-136. 